\title{
Fält, habitus och kapital som kompletterande redskap i professionsforskning
}

\section{CARINA CARLHED}

\begin{abstract}
Artikeln syftar till att undersöka på vilket sätt Bourdieus perspektiv kan bidra till en fördjupad förståelse av professionell praktik. I artikeln har Andrew Abbotts arbete om professioner som system valts ut som jämförelseperspektiv.

Hur kan Bourdieus ansats bidra till och komplettera professionsforskningen?
\end{abstract}

\section{Inledning}

Professionsforskning är ett expansivt, intressant område och lockar många forskare från olika discipliner, vilket innebär en mångfald av motiv och intressen. En del intresserar sig för yrkesgruppers expertauktoritet, legitimitet och status i relation till de nutida förväntningarna på flerdisciplinära samarbeten eller till rådande konkurrensförhållanden mellan yrkesgrupper. Andra intresserar sig för professioners

Carina Carlhed är forskarassistent och universitetslektor i utbildningssociologi vid Institutionen för pedagogik, didaktik och utbildningsstudier vid Uppsala universitet. Hennes professionsforskning rör särskilt medicin. tillblivelse och professionaliseringsprocesser, professionernas kunskapsbas och relation till vetenskapen, eller för gränsarbete, tillit och förtroende. Bland de teoretiska ansatserna som utvecklats i professionsstudier finns framförallt sociologiska teoribildningar som strukturfunktionalismen, nyweberianismen samt nyinstitutionalismen, men också nya tillskott som kombinerar vetenskapsteori och sociologisk teori (t.ex. Brante 2010). En intressant fråga är på vilket sätt Bourdieus sociologi kan vara ytterligare ett redskap i professionsforskningen, vilket föreliggande artikel ska försöka besvara.

I artikelns första del kommer jag att belysa vad Bourdieus specifika bidrag till professionsforskningen består i. I den 
andra delen jämförs hans ansats med ett dominerande perspektiv inom professionsforskningen, nämligen Abbotts teoretiska bidrag The System of Professions (1988), som genom sin stridsterminologi ytligt sett ligger rätt nära Bourdieus perspektiv och framförallt hans fältbegrepp, därav valet av hans arbete som en jämförelsepunkt.

\section{Bourdieus specifika bidrag till professionsforskningen}

\section{Socialisering till och reproduktion av fält}

Bourdieu har inte utvecklat en teoretisk begreppsapparat om professioner men väl om sociala praktiker - praxeologi (Bourdieu 1973, s 53), vilken i sin tilllämpning kan relateras till professionell praktik inom ett givet fält. När Bourdieu har studerat sociala sammanhang har han benämnt det som det sociala rummet. Under specifika tids- och rumsbetingelser kan ur det sociala rummet utvecklas ett socialt fält (Callewaert 1997, s 81). Ett viktigt grundantagande i fältbegreppet är att det sociala livet bygger på symboliska och kulturella trossystem med specifika trosföreställningar (doxor), med egna slags värderingssystem och dominansförhållanden, exempelvis vetenskapens fält, medicinens fält eller kulturens fält. Inom varje fält finns en förhärskande ordning, doxa - en tro på den "naturliga" ordningen. Ju längre historia ett socialt fält har samt ju högre grad av strukturering och kontroll, desto starkare kamp mellan konservativa krafter och utmanande krafter, som ifrågasätter doxan.

Bourdieu undersökte tidigt sociala praktiker i en specifik kontext - nämligen algeriska agrarsamhällen. Han använder ett brett anslag på sociala vardagliga praktiker, hur de uppstår och vad de innebär. Genom sitt antropologiska arbete utvecklade han där teori om hur vardagliga praktiker kan förstås i relation till sociala och symboliska ordningar i samhället - doxor (Bourdieu 1977). Dessa ses som objektiva sociala strukturer som både vägleder och begränsar sociala handlingar, t.ex. vad som anses passande eller inte, vad som är naturligt eller onaturligt. Utifrån dessa strukturer skapas ett likformigt system av dispositioner för perception, tänkande och handlande hos individen och som sätter sig i kroppen. Det är en slags inkorporerad historia men som samtidigt ger vägledning i nuet och de fortsatta handlingarna genom ett praktiskt förnuft. Detta system av dispositioner benämns habitus (Bourdieu 1990, s 56ff). Det är således utifrån den sociala och symboliska ordningen som handlingar får mening. Ansatsen kan erbjuda en djupare förståelse av de fält som inrymmer professionella praktiker, av såväl de professionella praktikerna själva, som deras reproduktion och förändring. Angreppssättet är dubbelriktat, å ena sidan genom att analysera det fullbordade verket opus operatum - de sociala och symboliska strukturerna och opus operandi, - hur de sociala strukturerna produceras och reproduceras (Bourdieu 1973, s 53). Det innebär att man inte kan förstå en handling utan att förstå dess relation till doxan samt hur den skapar en viss logik för handlingarna genom 
internalisering och förkroppsligande av sociala normer och strukturer i habitus.

Enligt Bourdieu är utbildningsystem bärare av samhällets viktigaste socialiseringsmekanismer och har även en stängningsfunktion. Men utöver själva sorteringen och inträdesbiljetten till en social position har också utbildningen en ideologisk funktion, dvs. den ger studenten motiv varför man gör som man gör samt varför man själv är viktig och till vilken position man tillträder och dess betydelse. Det ger en viktig inskolning i fältets logik och doxa. Utbildning fungerar därmed som ett slags verktyg för social reproduktion (Bourdieu \& Passeron, 2008, s 151ff). Utbildningens funktion i relation till professionsforskning och idén om utbildning som inträdesbiljett är relaterad till teori om sociala stängningsstrategier. Det Bourdieu ytterligare bidrar med utöver stängningsmekanismerna är studier av hur detta faktiskt går till, t.ex. genom språkliga klassificerande aktiviteter i klassrummen i Academic Discourse (1994) och genom klassificerande aktiviteter i selektering och initieringsriter till medlemskap av en akademisk adel State Nobility (1996a) eller mer generella studier av utbildningssystemet och dess omvandlingar i The Inheritors (1979) och i Reproduktionen(2008).

\section{Ett annorlunda "klassbegrepp"}

I Bourdieus syn på hur fälten befolkas och vilka dominansstrukturer som därigenom uppstår sker en upplösning av välkända begrepp som klass och profession. De analy- seras istället i termer av dominerande eller dominerade klasser/grupper, vars grund är den kapitalsammansättning man ärvt eller förvärvat. Individernas innehav och sammansättning av materiella och sociala tillgångar har betydelse för deras placering och relationer till andra individer i sociala sammanhang. Dessa tillgångar är vad Bourdieu kallar för kapital t.ex. ekonomiskt kapital, socialt kapital (tillgång till sociala nätverk, m.m.), symboliskt kapital (som definieras i relation till det specifika fält man studerar och som där erkänns som legitimt) och kulturellt kapital, som definieras i relation till de dominerande värderingarna i samhället t.ex. utbildningskapital och vetenskapligt kapital (Bourdieu 1996b, s 73ff). Kapitalsammansättningen hos en klass/grupp analyseras i relation till ett specifikt socialt rum eller fält samt i relation till andra klasser/grupper som är aktiva där. Detta ger möjlighet att fånga in sociala grupperingar i ett bredare socialt system än bara klass i vertikal mening (t.ex. överklass, medelklass och arbetarklass) genom att också ta med en horisontell dimension t.ex. polariseringen mellan olika kapitalformer (ekonomiskt vs. kulturellt kapital). Det är således inte bara utifrån den totala mängden av kapitalarter man får tillträde till vissa positioner i fältet, utan också utifrån den specifika sammansättningen eller arten av kapital.

Yrkesgrupper analyseras jämte andra organisationer och sociala grupper som aktiva i ett produktionsfält, t.ex. litteraturens, konstens, journalistikens, universitetens eller medicinens fält. Det som håller ihop fältet är intresset för att verka inom fältet och att göra anspråk på expertis. 
Genom att tala om yrkesgrupper istället för professioner blir inte frågan om vilken typ av profession den är (semi-/klassisk) styrande för analysen. I fältteoretisk konsekvens betraktas yrkesgrupper som en mobiliserad grupp, dvs. en social grupp som har kännedom om varandra och har kollektiva röster t.ex. genom ledarskap, facklig organisering och tidskrifter samt en någorlunda gemensam vision om vilka ställningstaganden gruppen har - ett slags kollektivt habitus med Bourdieus terminologi. En social grupp kan även ha sitt ursprung $i$ att från början vara en social kategori som utpekats i politiska sammanhang (t.ex. personer med funktionshinder eller vårdorganisatörer) men som organiserat sig. För att förstå fältets struktur, dvs. styrkeförhållandena mellan positioner, blir det därför också viktigt att ta med dessa andra grupper och deras positioner utöver yrkesgrupperna.

Yrkesgrupper och andra mobiliserade grupper bildar korporationer och bygger upp egna ideologier och kunskapsområden - ett "vi" i offentlig existens. Det behövs därmed politiskt arbete för att skapa grupper med formella strukturer för beslutsfattande och representation och som kan uttrycka en kollektiv åsikt. Ju närmare individerna befinner sig varandra i det sociala rummet (baserad på likartad kapitalvolym och kapitalart), desto större chanser att lyckas med samling och enighet i denna mobilisering (Bourdieu 2004, s 38). Genom att tala för sitt kollektiv och utifrån en gemensam ideologisk bas och kunskapsbas finner både yrkesgrupper och andra sociala grupper vägar för att kollektivt agera och delta i klassificeringsstriderna inom fältet. På så sätt deltar de i en ömsesidig uppbygg- nad av ekonomier av symboliskt kapital inom olika sociala fält, där samtliga i sin tur måste förhålla sig till det övergripande fältet, nämligen det byråkratiska fältet staten (Bourdieu 1995, s 83).

I en analys av hur habiliteringsområdet växte fram på 1960- och 70-talet visade det sig att handikapprörelsens organisationer hade stort inflytande på området och att allianser mellan yrkesgrupper och dessa organisationer skapade en tvinnad mobiliseringsrörelse i arbetet för "Saken", vilket i sin tur stärkte styrkeförhållandena mellan positioner och erkännande av expertis inom området (Carlhed 2007; 2008). Att föra in handikapprörelsens mobilisering och analysera dem som aktiva agenter i fältet, innebar således en brytning med oreflekterad vardagsförståelse hos allmänheten eller självförståelsen hos yrkesgrupperna att det är enbart professionerna och deras kunskapsproduktion och förtjänster som grundlagt området.

\section{Konsekrationsmakt inom och utanför fältet}

Bourdieus sociologi kan också fästa uppmärksamhet på hur överordnade positioner inom och utanför fältet skapar och eller legitimerar definitioner av sociala problem och kategorier. En viktig aspekt av sådant mobiliseringsarbete är fältets konsekrationsinstanser. Med vardagsspråk handlar det om att studera överinstanser som har möjlighet att legitimera aktiviteter i fältet. Staten har genom en överblickande och lagstiftande funktion skaffat sig en dominant position, med ett 
slags metakapital (som kan värdera och legitimera allt annat kapital), t.ex. Socialstyrelsen, Högskoleverket och Skolverket eller parlamentariska utredningar. Men för yrkesgrupperna kan det handla om mer närliggande positioner som fackliga/politiska centralorganisationer eller intresseorganisationer. Sådana instanser kan fungera konsekrerande genom att de som sitter på dominanta positioner utanför fältet också kan vara verksamma inom fältet, t.ex. att yrkesgrupper har inflytelserika personer med dubbla tillhörigheter och ett betydande kapitalinnehav vad gäller inomfältsligt administrativt kapital i kombination med statbyråkratiskt kapital.

Konsekrera betyder heliggöra, på så sätt bidrar t.ex. statliga betänkanden till uppbyggnaden av symboliska värden och att visa vilka ställningstaganden eller aktiviteter som anses värdefulla. Exempel på symboliska produkter som skapas i denna klassificeringsprocess är sociala problem som forskare och myndigheter försöker att göra något åt. Utredningarna tjänar därmed till samling och bestämning av hur saker och ting ska värderas och benämnas, vilket blir tydligt i lagstiftningen.

Ett konkret exempel på konsekrationseffekter är Socionomutredningens betänkande 1962 som utrangerade Sköndalssocionomerna som legitima socionomer. Det bidrog till förnyad kraft för de konsekrerade "riktiga" socionomerna i sitt gränsarbete mot de förra och man hämtade formuleringar från betänkandet som argument $\mathrm{i}$ intensiva debatter. Socionomutbildningens förstatligande och dess efterspel ger också ett tydligt exempel på mobilisering det vill säga hur man som grupp kan ikläda sig en definition från t.ex. ett överordnat fält och sätta upp nya gränser för ett "vi". Med upphöjandet från en modest tillvaro till en annan av högre dignitet börjar en social magi att verka i att uppfylla definitionen. Men det innebär också att man träder in i doxans tysta överenskommelser och återgäldar "gåvan" (att bli konsekrerad) genom tacksamhet och lojalitet som motgåva, (se vidare Carlhed 2007, s 36, 285, 324). Ju mer konsekrerad individen/gruppen är desto mer är den också benägen att konsekrera objekt som är skapade inom doxan, vilket också innebär en tendens till reproducerande handlingar (Bourdieu 1992, s 159).

\section{Doxans räckvidd och gränsområden}

Det finns en risk inom professionsforskningen att man betraktar yrkesgrupper som homogena, även om det finns en tydlig differentiering inom dem. Fraktioner kan arbeta i olika sociala fält, t.ex. kuratorer verksamma i huvudsak inom hälso- och sjukvården i nära samarbete med andra medicinska yrkesgrupper. De kan då i ett Bourdieuskt perspektiv även betraktas som aktiva inom det medicinska fältet. Lekterapi försiggår inom sjukhusets väggar, men bedrivs av pedagogiskt skolad personal, och bör då betraktas som aktiva i det medicinska fältet, verksam under den medicinska doxan. Det innebär att det praktiska arbetets inriktning, det nära samarbetet med andra yrkesgrupper och organisationstillhörigheten, har stor betydelse för vilka strategier yrkesgruppen eller fraktionen väljer 
samt enligt vilken fältlogik de mest fungerar. I studien av habiliteringens framväxt framstod organisationerna som formats efter målgrupperna ha varit de huvudsakliga naven i uppbyggnaden av en ekonomi av symboliskt kapital. Genom grupperingarnas investeringar i och strider om definitionsrätten till ett visionärt område "habilitering" överskreds både de organisatoriska gränserna och yrkesgruppernas "hemmaplaner" samt yrkesgruppernas gränser. De doxiska gränserna i fältet tydliggörs om man ser till de sanktioner som skapas för dem som bryter dessa gränser. Detta har bland annat synliggjorts i Carlheds studier (2007; 2008) med bl.a. förskollärarna som skolats i en pedagogisk doxa med barnet som odelbart objekt. Medicinens objekt inom habiliteringsrummet var däremot ett diametralt annat objekt - det delbara barnet. Att verka inom ett annat fält än det egna, innebär att man är verksam i organisationer som domineras av en annan doxa, än den man inskolats i. Yrkesgrupper prövade på att byta fält, t.ex. en sjukgymnast som kallade sig skolergonom och som ville in i skolans värld. Hennes symboliska kapital från den medicinska doxan gällde inte i det nya fältet och erkändes inte av den pedagogiska doxans företrädare, men inte heller av sina egna sjukgymnastkollegor. Sanktioner från egna kollegor mötte också förskollärare som arbetade med handikappade barn på 1960-talet. Det fanns med andra ord inget kollektivt stöd för kollegor som lämnat sina "hemmafält" för verksamhet inom andra fält, samtidigt som man mötte på motstånd i det nya. Bourdieus ansats kan bidra till förståelse av de sociala fältens logik och skyddande barriärer, avgränsande både för de som är inom fältet och för de som är utanför fältet, samt vad det innebär att arbeta på "hemmaplan" inom sitt eget fält eller på andras fält dvs. på "bortaplan". Här kan fältbegreppet och doxabegreppet belysa varför och på vilket sätt en jurisdiktion vinner kraft eller inte. Det är lika intressant att lyfta fram det som det talas om, likaväl det som det inte talas om - dvs. det som är tabu och misskänt.

Analyser koncentrerade kring fältens doxa, talar i professionsforskningssammanhang för att fältbegreppet fungerar allra bäst på yrkesområden med stark strukturering och med en stark doxa, t.ex. medicinen och juridiken. Men fältbegreppet kan med fördel användas i studier av gränsområden och dess strider genom att t.ex. ta med grupperingar som sysslar med samma "sak", som i fallet med psykoterapins gränsstrider under 1970-talet mellan psykiatrer, psykologer och socionomer. Striderna gällde vilken den mest värdefulla grundutbildningen var för att bedriva psykoterapi och vad klienterna skulle betala (Carlhed 2007 , s 120, 245, 333). Ett annat exempel är skolpsykologin under 1970-talet, där kontrahenterna var forskarutbildade psykologer och lärare med påbyggnadsutbildning i psykologi. Striderna handlade bl.a. om skolpsykologins organisation och om rättigheter att inneha tjänst som skolpsyko$\log$. Detta tolkas som uttryck för klassifikationsstrider och gränsstrider som uppstår när representanter från ett fält träder in $\mathrm{i}$ ett annat och det problematiska att kombinera symboliskt kapital från ett fält till ett annat (Carlhed 2007, s 68ff).

Psykologins ökade inflytande i socionomutbildningen blev ett debattämne 
framförallt från mitten av 1970-talet då alltfler socionomstudenter sökte psykologi som huvudämne istället för sociologi. Vid samma tidpunkt uttryckte socionomstudenter dock att det var gränsen till medicinen som upplevdes mest problematisk (Socionomförbundets tidskrift 1975, nr 4, s 8-9). Stina Wingfors har visat att SSR var kritiska mot innehållet i grundutbildningen när det gällde socialsocionomerna. Man ville att de skulle få medicinska och pedagogiska baskunskaper. Wingfors menar att om SSR fått gehör för införandet av medicinska baskunskaper i utbildningen hade detta medfört att de erhållit den efterlängtade legitimationen likt de andra statligt legitimerade professionerna (Wingfors 2004, s 188ff). Relationen till det medicinska fältet kunde med andra ord skapa möjligheter till symboliskt uppåtstigande, här i form av en legitimationsfråga, även om socionomerna som helhet inte tillhörde det medicinska fältet utan bara kuratorerna. Men man kan fundera kring konsekvenser av tendensen till socionomstudenternas utrangering av sociologi som huvudämne (till fördel för psykologin) och socionomernas närmande till det medicinska fältet.

Studier med fältbegreppet som verktyg kan bidra till ytterligare förståelse av differentieringen inom yrkesgrupperna och deras orientering mot olika sociala fält, genom att bryta upp yrkesgrupper i mindre fraktioner och undersöka vilka värden och andra yrkesgrupper de söker sig mot. Detta är högst aktuellt $i$ vår tid då man nu kan se en allt ökande andel av samverkansorganisationer, centrumbildningar och nätverk som går på tvärs genom organisationer och yrkesgrupper. Att organisation har stor betydelse för förståelsen av professioner är i och för sig inget nytt (se Svensson 2010, s 33ff). Fältbegreppet kan däremot hjälpa till att definiera organisationers hemvist, fysiskt men också doxiskt och därmed öka förståelsen av intersektionernas konsekvenser. Doxabegreppet kan visa hur starkt ett fält är strukturerat och hur långt dess kraft räcker för att attrahera individer/klasser/ grupper. Den dominanta doxan tar med andra ord inte hänsyn till vare sig professionsgränser eller organisationsgränser, då den kan verka långt utöver sådana gränser. Framväxten av nya fält eller subfält kan förstås utifrån heterodoxa poler, där grupper mobiliserar sig. Man kan också uttrycka det som en slags institutionalisering av anomin, dvs. "hur det går till när ett avantgarde överträder alla gällande regler för en verksamhet, institutionaliserar sig som avvikare, för att slutligen bli den allmänt gällande regeln i ett fält" (Callewaert 2006, s 337). När det gäller habiliteringsområdets utveckling, handlade det om att i det medicinska fältets utkant, i gränslandet mellan det reproduktiva fältet (skola, förskola) och det socialbyråkratiska fältet (socialtjänst) bildades ett nytt socialt rum, där barnläkare och barnpsykiatrer (som hade låg status i det egna fältet) i allians med socialpolitiska agenter och genom symbolisk maktutövning, blev det nya subfältets "herrar" (Carlhed 2007). Genom doxabegreppet kan människors investeringar och aktiviteter även förstås utifrån drivkrafter sprungna ur den mening de lägger i sina handlingar, dvs. de "tror" på att de handlar rätt utifrån deras habitus, i en "naturlig ordning". Men den sociologiska analysen visar konsekvenserna av historiska inves- 
teringar i termer av sociala och kulturella strukturer som produceras, reproduceras och förändras.

\section{Likheter och skillnader mellan Abbotts och Bourdieus ansatser}

I denna del av artikeln sker en jämförelse av Abbotts professionssystem och Bourdieus fältbegrepp och då särskilt produktionsfält, som kan vara relevant när man studerar professionella praktiker. Jämförelsen berör teman så som relationellt tänkande, teori som öppna ramverk, konfliktfokus och olika nivåer för konflikterna, mytbildning, kunskap som legitimerande funktion och slutligen autonomifrågan.

\section{Teori som ramverk eller öppna program}

Både Abbott och Bourdieu arbetar empiriskt och ser det som den huvudsakliga utgångspunkten för sociologisk teoriutveckling. Båda förespråkar löst hållna definitioner. Abbott gör det på följande sätt: "Professions are exclusive occupational groups applying somewhat abstract knowledge to particular cases" (Abbott 1988, s 8). Abbots intresse är riktat mot utvecklingen av professioner i ett oberoende system, deras inbördes relationer och i ett vidare perspektiv för sätten de kontrollerar kunskap och färdigheter. Professionernas jurisdiktioner är således inte absoluta eller permanenta utan förstärkningarna eller försvagningarna etableras $i$ processer av faktiskt professionellt arbete. Abbotts arbetssätt med en lös definition kan relateras till Bourdieus beskrivning av sin egen ansats med öppna begrepp som ger full mening när de omsätts i studier. Det finns t.ex. ingen entydig definition av fält eftersom det ger mening när det används empiriskt. Begreppen fält, kapital och habitus hänger samman, vilket innebär att man ser det relationella i dessa tre begrepp, inget av dem kan förstås utan de andra. I kartläggningen av kapitalarter, kapitalsammansättning och ställningstaganden hos de individer, grupper eller institutioner som är aktuella, innebär detta en prövande och iterativ process av vad som faktiskt gäller i det aktuella fallet då dessa är beroende av fältet. Ett exempel på en tillämpning av en sådan öppen ansats är Carlheds studie där en bred provisorisk definition av habiliteringspraktik användes: praktiker som syftar till att monopolisera vetande om att ta hand om barn och ungdomar med handikapp. Att utgå från termen "habilitering" hade varit förödande, då man riskerar att bara leta efter sammanhang där ordet "habilitering" dyker upp. Genom den bredare definitionen kunde en mångfald av praktiker identifieras som viktiga i habiliteringens framväxt och en bild av dess genes kunde tecknas, men också många alternativa vägar utvecklingen kunnat ta. Utifrån den provisoriska definitionen i samband med en första fas i insamlandet av empiri från yrkesgruppers och handikapporganisationers tidskrifter blev det uppenbart att habilitering inte kunde betraktas som ett autonomt fält. Under datainsamlingens tidiga fas syntes allt fler tecken på att det var det medicinska fältet och läkarna som 
hade dominanta positioner rörande vård och undervisning av barn och ungdomar med handikapp (se Carlhed 2007, 43ff). Man kanske har ambitionen att studera ett fält som man tror kan vara autonomt, men det visar sig efterhand att det är ett delfält eller subfält till ett större fält.

\section{Systemiskt, relationellt tänkande och konflikt}

Abbott arbetar tydligt efter ett systemteoretiskt tänkande som i generella termer innebär att det systemiska och relationella går förlorat om man studerar enbart en del av systemet. Det innebär en syn där helheter, dynamisk interaktion och organiseringsprinciper fokuseras och där man vill utveckla generell kunskap om likformiga/ isomorfa principer, stabilitet och instabilitet i systemen (Capra 1997, s 45). Systemteorins tanke om "öppna system" som fungerar genom ett kontinuerligt flöde och förändring, kan klart relateras till Abbotts idé om professioner som system och hans terminologi t.ex. disturbances, system change, och equilibrium (Abbott 1988, s 91, 109). I en senare artikel utvecklar han sin begreppsapparat genom begreppen linked ecologies i betydelsen relationer mellan olika ekologiska system, t.ex. mellan det professionella systemet och externa relationer till staten eller universitetet. Hinges och avatars är olika former av externa relationer (Abbott 2005).

Bourdieus perspektiv är i likhet med Abbott relationellt, vilket innebär att den sociala verkligheten består av relationer mellan positioner och strukturer. Det är relationerna mellan olika sociala intressen och grupper som bör vara i fokus för en sociologisk analys. Analytiskt kan fältet sägas bestå av två homologa rum, ett rum av möjigheter och ett rum av sociala positioner. I rummet av möjligheter regerar den specifika symboliska ekonomin, vilande på de fältspecifika trosföreställningarna "doxan" som i sin tur skapar en viss logik i fältet. De individer som har en hög andel kulturellt kapital och specifikt symboliskt kapital bildar en autonom pol i fältet, där doxan är som starkast och inte ifrågasätts. I motsättning till denna autonoma pol finns en mer heterodox pol eller profan pol, där strider om doxan sker och där influx sker i form av värden och praktiker som i sig utmanar doxan. Denna polarisering kan också iakttas om man väljer att studera ett mindre utsnitt ur fältet. Symbolsystem som det är fråga om här har några grundläggande uppdelningsprinciper t.ex. helig/ sakral-profan, enighet-oenighet som kan användas till att förstå olika sociala differentieringsprocesser (exklusion-inklusion, association-dissociation etc.) som kan användas politiskt för att legitimera differentieringsprocesserna, med andra ord skapa härskartekniker (Callewaert 1998, s 25). Rummet av sociala positioner bygger däremot på individernas/gruppernas sociala och materiella tillgångar i termer av kapital. De båda rummen har varsin egen logik och positionerna i rummen relaterar sig i första hand till varandra, men om fältet uppnått tillräcklig autonomi eller jämvikt kan det finnas en homologi mellan dem. Den styrande principen finns då i rummet av sociala positioner (Bourdieu 2000, 335ff). Med andra ord beror fältets 
relativa autonomi på fältets sociala förankring och resursfördelning.

Stridsterminologin och fokus på konflikt är annars kanske det man först kommer att tänka på i jämförelse mellan ansatserna. Exempel på termer som Abbott använder är; attack, invasion, nederlag, kraftigt våld i striderna om jurisdiktionen och dess gränser, och professionernas verkliga historia består av konsekvenserna av dessa strider. (Abbott 1988, s 2, 33, 69). Bourdieu använder också rikligt med ord som konnoterar konflikt t.ex. kamp, strid, symboliskt våld, men använder också i stor utsträckning andra termer från det ekonomiska området; kapital, investering, spel, intresse och från det magiskt/religiösa området med termer som; doxa, ortodox, heterodox, konsekration, social magi, kättare, tabun. Fältbegreppet kan lätt tolkas som enbart konfliktinriktat. Men sett från de kulturella dimensionerna i Bourdieus sociologi, så handlar det även om att förstå människors symboltänkande och symbolhandlande som kulturella varelser och vilken mening de lägger i sina handlingar. Bourdieu utgår inte självklart från att det bara är stridsinstinkter och maktanspråk som driver människor, utan även en tro på det man gör som något seriöst och osjälviskt, att man arbetar för och investerar tid och engagemang i "Saken" och inte strider på något fält. Hans användning av stridstermer kanske skymmer detta, men är alltså en central aspekt i fältteorin. Dock ska drivkrafterna och självförståelsen hos individerna och/eller grupperna sättas inom parentes, eftersom de sociologiska förklaringarna till varför de gör som de gör inte går att finna där utan måste rekonstrueras fram, dvs. i dialektik mellan deras dispositioner, fältets struktur och den mening de lägger i sina handlingar.

När det gäller det relationella, avser båda perspektiven att begreppsapparaternas delar ska användas tillsammans. De syftar till analyser av gruppernas kulturella legitimitet och hur de på olika nivåer samverkar och stärks eller motverkas. Hos Abbott sker detta på de tre arenorna; legala, mediala och på arbetsplatsen samt genom länkade ekologier. Hos Bourdieu analyseras kulturell legitimitet utifrån habitus och innehav av symboliskt kapital i relation till det specifika fältet samt till andra fält och till det sociala rummet (samhället).

Skillnaden mellan Bourdieus fält och Abbotts systembegrepp är att Abbott betonar gränserna i systemet, vilket är värdefullt om forskningsintresset riktas åt det hållet. Bourdieu har mer fokus på det som håller samman fältet, kulturellt och symboliskt dvs. doxan och dess relationer samt striderna om densamma (Bourdieu 1977, s 167). Abbott är mer renodlat konfliktinriktad i sina analyser medan Bourdieu även fångar in mer kulturellt liv i sina analyser och lägger tyngd på relationerna mellan de kulturella uttrycken i relation till den sociala strukturen i samhället. Trots de många konnotationerna till strid och konflikter i Bourdieus fältbegrepp finns det utrymme för analyser av möjliga samarbeten och allianser, då det är mobiliseringen kring vissa symboliska värden och deras polarisering som skapar reella plattformar för samarbeten och ny kunskapstillväxt. Fältbegreppet möjliggör således en dubbelinriktad analys av både kamp och samarbete (i form av allianser) i fältet, där en social och symbolisk struktur kan tecknas. Tonvikten ligger dock på kampen i fältet. 
Till skillnad från Bourdieu fokuserar Abbott på yrkesgruppernas medvetna strategier för att vinna makt, status och anseende och har utarbetat typologier av vilka sorters attacker som kan förekomma yrkesgrupperna emellan samt av hur de jurisdiktionella konflikterna finner lösningar. Yrkesgruppernas expansion av sina expertområden och yrkesgruppers försvinnande verksamhetsområden kan därmed förstås utifrån konsekvenser av en medveten och strategisk (i ordets sanna bemärkelse) medveten krigsföringslogik, vilket ger en annorlunda vinkel än vad Bourdieu bidrar med.

\section{Mytbildning}

I Abbotts sätt att se på hur professionerna gör anspråk på jurisdiktioner är han mycket precis i hur detta går till. Detta kan ske genom att de skapar bilder (images) på den publika arenan av professionen och deras förmåga att handskas med vissa arbetsområden för att sätta press på det legala systemet. Grundelement i detta imageskapande för publika jurisdiktioner är anspråk på social och kulturell auktoritet (Abbott 1988, s 60). I denna imageskapande process skapas också myter om professionen som homogen med skarpa gränser med objektivt definierade uppgifter, som gör deras aktiviteter lätta att förstå sig på och att de också framstår som effektiva. I syftet att väcka sympati hos allmänheten för professioner och deras arbete är massmedia viktig, där TV, dagspress och tidskrifter är centrala kanaler, men även talkshows och fiktion (Abbott 1988, s 60-61). Abbott kan även ge detaljerade förklaringar på hur angrepp kan ske, t.ex. genom kognitiva strategier, som syftar till att försvaga eller förstärka professionens legitimitet. Exempel på kognitiva strategier är reduktion (omdefiniera andras jurisdiktioner till sin egen struktur) eller genom att upprätthålla maximal abstraktion (professionella samlas under en bred beteckning, t.ex. medicinen) eller specialisering (nya jurisdiktioner) (Abbott 1988, 99, 105).

Avseende sådant imageskapande enligt Bourdieu spelar förhållandet mellan doxa och diskurs en stor roll dvs. det som ligger till grund för vad man gör kontra det man talar om att man gör och där mytbildning i form av "tabut mot det klart uttalade" eller kollektivt misskända har en central roll (Bourdieu 1995, s 146-147, 157). I Carlheds studie exemplifieras detta med läkarkårens konflikt mellan sin fackliga organisering som ett kollektiv med krav på löner och andra uttalade förmåner, mot den paradoxala mytbildningen utifrån kalltanken i Hippokrates ed - dvs. den ensamme altruistiske läkaren vid sängkanten (se vidare Carlhed 2007, s 68ff och Eklöf 2000, s 253-254). Imageskapande sker också genom symbolisk makt som förstås som ett slags "representationens magi" vilket innebär härskande över symboler (Bourdieu 2005). De positioner som dominerar fältet har inflytande över vilka symbolerna är och dess värden. På så sätt igenkänns och erkänns de som har en hög andel symboliskt kapital i fältet av dem som socialiserats in i ett fält (Bourdieu 1995, s 152, 154). Striden inom fältet gäller således rätten att klassificera vad som är värdefullt eller vilka aktiviteter som ger erkännande och anseende. Symbolisk makt kan således fungera mobiliserande men aldrig utan själva erkän- 
nandet i kombination med ett kollektivt misskännande, det vill säga att den symboliska makten tillskrivs en "naturlig" auktoritet (Bourdieu 1991, s 170).

Striderna om expertis innebär olika strategier i att erövra vetandemonopolet. Abbott menar att en basal mekanism för interprofessionell strid är då professioner använder sina abstrakta kunskap till att reducera motståndares arbete till egen version, exemplet reduktion nämndes tidigare (Abbott 1988, s 36). Här finns det intressanta likheter med fältbegreppet, då ett relativt autonomt fält kan importera och översätta teman och problem från omvärlden till sin egen diskurs (Broady 1991, s 268). I Carlhed (2007) ges exempel på detta av de socionomer som arbetade som kuratorer inom hälso- och sjukvården och som stöptes om till medicinalpersonal 1965, fastän de var upp till $97 \%$ socionomer (Ibid., s 269, 256).

Abbotts begrepp är som nämnts tidigare mer utarbetade och ger en mer detaljerad bild av hur importen eller "stölderna" går till, bl.a. genom olika kognitiva strategier. Men liknande företeelser kan alltså även analyseras med fältbegreppet. Hos Bourdieu är också språket i sig socialt och utgör en avgörande medierande och inkluderande/exkluderande faktor, men ges däremot inte utrymme i Abbotts analyser. Återigen är det kulturens betydelse som blir en viktig skillnad mellan dem.

\section{Kunskap som legitimerande resurs}

Abbott ger substantiell hjälp om man är intresserad av att utveckla teori kring professioner som system och erbjuder möjligheten att i detalj studera hur relationen mellan arbetsuppgift och abstrakt kunskapssystem kan förstås. Abbott ger en fördjupning av professionernas relation till den abstrakta kunskapen och hur de använder den. De uppgifter som professionerna gör anspråk på har objektiva och teoretiska kvaliteter, som gör att områden som mekanik, kirurgi, ortopedi och teknik kan sägas höra samman. Men uppgifter har också subjektiva kvaliteter, som skapas i den aktuella konstruktionen av problemet enligt den specifika jurisdiktionen som professionen försöker upprätthålla. Relationen mellan det abstrakta kunskapssystemet och professioners arbete kan med Abbotts ansats analyseras med begreppen diagnos, inferens och behandling (Abbott 1988, s 35-58). När det gäller den abstrakta kunskapen menar Abbott att akademisk kunskap främst används i legitimerande syfte, i forskning och undervisning. Professionens förmåga att behålla sin jurisdiktion beror då på den grad av makt och prestige deras akademiska kunskapssystem har.

Kunskapens legitimerande funktion liknar också Bourdieus sätt att se på det hela. Båda anser att det abstrakta kunskapssystemet i stort sett bara finns i professionella läroböcker, om vi talar med Abbotts formulering (Abbott 1988, s 56). Bourdieu skiljer på praktikerns praktiska förnuft som har en egen logik, från det skolastiska synsättet. Med anledning av detta talar Bourdieu om det skolastiska felslutet som innebär: "att man lägger meta-diskursen till grund för diskursen, metapraktiken till grund för praktikerna" (Bourdieu 1995, s 
185; se också Callewaert 1999 och Petersen 1996, 2004). Vår spontana vardagslogik ger ofta en bild som om man tillämpar teori i praktiken, men praktikerns handlande är mycket mer komplext än så menar Bourdieu. Det professionella handlandet har sin grund i framförallt egna ackumulerade erfarenheter, i habitus, och bär delvis influenser av t.ex. det kunskapsinnehåll som en yrkesutbildning förmedlar - men den vetenskapliga kunskapen styr inte primärt handlandet hos den professionelle.

\section{Autonomi}

Abbotts huvudtes om professionerna som ett specifikt, relativt autonomt socialt system står i konflikt med Bourdieus tes att det är större sociala fält med relativ autonomi i över- resp. underordning som anger ordningen i det sociala rummet. Fältbegreppet löser upp det professionella systemet genom att ta med andra grupperingar än de professionella inklusive de s.k. expertsystemen hos Abbott. Yrkesgruppers framgång i sitt kunskapsmonopol och jurisdiktion beror på, om man nu skulle översätta det med Bourdieus fältbegrepp, således mycket på allianser med andra slags organisationer och positioner än de yrkesmässiga eller professionella sammanslutningarna. Fälten är således inte bara "professionella fält" utan omfattar många andra aktörer som bidrar till kunskapsproduktionen och till dess symboliska värdehierarkier genom sina positioneringar. Författare är t.ex. inte bara beroende av förläggarstrukturen utan också beroende av litteraturvetare, tidskriftsägare, kriti- ker, journalister och sin publik samt andra agenter inom kommersiell media (TV, radio, dagspress). Fältets relativa autonomi avgörs av i vilken grad de inblandade är mer beroende av varandra än av andra utanför fältet. Det som avgör tillhörigheten är att grupperingar måste vilja göra insatser i spelet och vara förtrogna med reglerna, dvs. ha en habitus som "innefattar både kunskap om och erkännande av spelets inneboende lagar, dess instanser etc. Det är fältet som ger plats (Bourdieu 1992, s 55-76, 160-161) vilket också bryter med den ideala bilden att professionen mycket av egen kraft skapar sin tillvaro.

Men Abbott menar inte att professionerna själva alltid kan skapa plats i ett verksamhetsfält, utan att vakanta områden skapas dels utifrån eller också av att nya professioner inom systemet söker nya grunder, nya strukturer, ny teknik eller att organisationsutveckling kan stänga eller öppna vakanta områden. Abbott är således ingen förespråkare av att professionerna är allsmäktiga. Det är enligt hans sätt att se de ekologiska förutsättningarna i systemet som bestämmer vilken roll de interna initiativen lyckas och de bästa förutsättningarna finns i professionens mest legitima hemvist "heartland" (Abbott 2010, s 77, 176), som är jämförbar med fältets autonoma pol i fältteoretisk mening.

Skillnaden här är att Abbott har fokus på professionerna som entitet medan Bourdieu har ett bredare grepp genom sitt fältbegrepp, vilket också kan innefatta relationer, som Abbott definierar utanför systemet. Abbott använder termen expertsystem men då förbehållet specialiserade grupper som kan bestå av professionella 
från flera professioner men som samlas kring ett visst område t.ex. AI - artificiell intelligens och som främst tävlar med de relativt välutvecklade professionerna som t.ex. medicinen (Ibid., s 182). Det vidgar möjligen hans grepp om professionella praktiker, men fokus blir något suddigare i talet om dessa expertgruppers roll och varför inte dessa betraktas som en del i det professionella systemet. Abbott menar visserligen att man måste studera flera professioner åt gången och gärna inom större områden (task areas och turf zones) eftersom de där skapar sin existens i de jurisdiktionella striderna (Abbott 2010, s 175, 184). Men det professionella systemets autonomi i relation till världen utanför t.ex. expertsystemen är enligt min mening något oklar i hans bok The Systems of Professions (1988). Han kompletterar dock senare sin begreppsapparat med begreppen linked ecologies, hinges och avatars som kan bidra till förståelsen av externa relationer mellan profession och staten samt universitetet och hur aktörer söker allianser, resurser och stöd över systemens gränser (Abbott 2005, s 247). Där utvecklas relationerna till staten och universiteten, men det kvarstår om dessa teoretiska tillskott skulle kunna förklara det professionella systemets oberoende eller beroende till andra verksamheter utanför systemet, t.ex. vissa läkargruppers beroenderelation till läkemedelsindustrin.

När det gäller yrkesgruppernas relation till staten och dess styrning kanske fältbegreppet å ena sidan kan passa bättre i länder med stark statsstyrning än Abbotts systembegrepp eftersom staten i hans perspektiv dels förmodas ha en svagare makt och dels definieras utanför det professio- nella systemet (han diskuterar dock kontinentala sammanhang med starkare styrning från staten) (Abbott 1988, s 60) Hans bidrag från 2005 ger förståelse av professionernas relation till staten, men då avser det en stat i en amerikansk kontext. Fältbegreppet är mer öppet och kan omfatta t.ex. personer i yrkesgrupper som innehar positioner i maktfältet som direkt kan påverka lagstiftningen, dvs. en slags dubbel tillhörighet. $\AA$ andra sidan har neoliberalismens intåg ökat marknadens betydelse $\mathrm{i}$ de kontinentala länderna, vilket innebär att de angloamerikanska teorierna nu mer än förr kan bidra till förståelsen av professioner, organisationer och marknadskrafter (se Svensson och Evetts 2010, s 13ff).

\section{Sammanfattning}

I denna jämförande del har det framkommit likheter och skillnader mellan Abbotts och Bourdieus perspektiv. Likheterna handlar om deras konfliktperspektiv, relationellt tänkande, syn på empirisk forskning som den "riktiga vägen" för sociologin, att arbeta med lösa/provisoriska definitioner och med begreppsapparater som ramverk eller program, som behöver sättas i rörelse och fyllas med empiriskt innehåll för att nå full potential och mening. Det finns likheter även avseende synen på att målet för striderna är att vinna kulturell legitimitet där en primär metod är att skapa image eller myter i denna process. De delar också betoningen på strukturellt agentskap. När det gäller den legitimerande funktionen av kunskap är de relativt eniga. Abbott har dock i tillägg detaljerade resonemang om 
professionens relation till abstrakt akademisk kunskap och hur den används, vilket inte Bourdieu har specifikt fördjupat sig i. Andra skillnader är deras syn på gränser och kärnområden, där Abbott fokuserar gränserna, och Bourdieu det som håller samman fältet. Bourdieu lägger mer fokus på kulturella och symboliska maktstrukturer och deras sociala reproduktion, vilket inte Abbott intresserat sig för. När det gäller konfliktperspektivet är dock Abbott dess främsta företrädare, medan Bourdieu menar att det är andra drivkrafter som tro och övertygelse, som är mer verksamma än medvetna försök att avgränsa kunskapsoch uppgiftsområden.

\section{Konklusion}

Artikeln syftade till att undersöka vad Bourdieus perspektiv tillför och hur det kan komplettera professionsteori. Det specifika bidraget består för det första i hans beaktande av socialiseringsmekanismer till fälten. För det andra löses begrepp som profession och klass upp och ger ett bredare perspektiv på dominansrelationer mellan dessa klasser som skapar sociala och kulturella strukturer/hierarkier samt sammanhållning och drivkrafter i fältet.

När det gäller socialiseringsmekanismerna handlar det om hans praxeologiska perspektiv, som studerar sociala praktikers logik dels i de objektiva strukturerna och dels de dispositioner de producerar/ reproducerar i en dialektik mellan kroppar, institutioner, ritualer etc., vilket gör att man kan studera hur det primära vetandet blir möjligt. Detta perspektiv innebär både att man studerar det fullbordade verket opus operatum och opus operandi, dvs. hur det fullbordade verket skapas. Detta innebär enkelt uttryckt en grundsyn på människors habitus som en form av förkroppsligad historia skapad genom livsbetingelser och som leder dem i sitt handlande i den sociala världen. Dispositionerna styr in deras handlande så att den sociala världen tenderar att reproducera sig och all perception filtreras genom habitus, vilket gör förändring trög. Denna grundsyn genomsyrar hans perspektiv och innebär att man inte kan förstå en handling utan att förstå dess relation till den rådande sociala och symboliska ordningen och hur dessa skapar logik för handlingarna genom kulturella socialiseringsprocesser.

Samhällets utbildningssystem är bärare av de viktigaste socialiseringsmekanismerna dvs. kulturell överföring av mentala strukturer och sociala klassificeringssystem. Utbildning har således en reproducerande funktion och fortsätter att forma människors habitus genom att omvandla nedärvt kulturellt kapital till akademiskt kapital och på så sätt införliva vilken plats man har i den sociala världen. Detta perspektiv kan i sin tillämpning ge möjligheter att undersöka hur socialisering sker till en professionell praktik inom ett givet fält. Inskolningen till ett fält är inte en process som börjar den dag man kan titulera sig läkare eller lärare eller socionom, utan långt tidigare. Detta är vad Bourdieu menar med att studera opus operandi, hur den sociala och kulturella ordningen blir möjlig. Man kan genom förståelse för fältens sociala reproduktion och vilka sociala strukturer som upprätthålls, ge ytterligare 
en dimension i förståelsen för professionell praktik, dvs. en förklaringsgrund till vilka som befolkar dessa fält och praktiker, dvs. efter vilka mekanismer som reproduktionen sker till fälten eller som medverkar till förändring av dem.

I studiet av fältet - det fullbordade verket opus operatum, upplöses välkända begrepp som professioner och klass och analyseras istället i termer av dominerande klasser/grupper eller dominerade klasser/ grupper, vars grund är den kapitalsammansättning man ärvt eller förvärvat. Värdet av dessa kapital ställs mot fältets doxa som värderar dem som legitima eller ej i olika grad, vilket i sig skapar en specifik ekonomi av symboliskt kapital. Det är således större sociala fält med relativ autonomi i överresp. underordning som så att säga anger ordningen i det sociala rummet. Bourdieu kan på så sätt ge mer precis innebörd i vad kulturell legitimitet innebär för yrkesgrupper och deras professionella praktik - men då i termer av socialt, ekonomiskt, kulturellt och symboliskt kapital. Fältbegreppet bidrar också till att förstå hur den kulturella legitimiteten kan underlättas genom relationerna mellan dominanta positioner inom ett fält och deras relationer till andra dominerande fält, som t.ex. de dubbla tillhörigheterna som personer kan ha i ett yrkesfält och till maktfältet.

Hans ansats rymmer också möjligheter att på ett djupare plan analysera människors drivkrafter och strategier och deras tro på de egna investeringarna, i relation till språkliga och meningsskapande symboliska strukturer - doxa och fält. Upplös- ningen av det traditionella klassbegreppet och professionsbegreppet ger ett bredare perspektiv på hur olika grupper/klasser kan relateras till varandra samt deras praktiker utifrån såväl sammanhållande krafter som interna polariseringar. Bourdieus klasser ger därmed professionsteorin en fördjupad klassdimension inklusive en reproduktionsdimension.

I jämförelsen av Abbotts och Bourdieus ansatser framkommer en del likheter men också skillnader, vad gäller ansatsernas syfte, ontologi, analytiskt djup och bredd. Bourdieus ansats kan sägas bottna $i$ en emancipatorisk tanke, där ett primärt mål är att synliggöra förgivet tagna sociala och kulturella dominansrelationer och deras reproduktion samt konsekvenser i form av symboliskt våld. Någon sådan emancipatorisk tanke är inte synlig i Abbotts arbete. Uppbrytningen av klassbegreppet medger också möjligheten att synliggöra mer komplexa dominansrelationer där dominanta/ dominerade klasser tvinnas med köns- och etnicitetsaspekter. Abbott visar inte upp någon analys av klassaspekter eller social reproduktion. Abbott visar däremot med precision hur yrkesgruppernas expansion av sina expertområden och yrkesgruppers försvinnande verksamhetsområden kan förstås genom medvetna, taktiska strategier, vilket Bourdieu inte gör. Bådas ansatser bidrar dock till strikt sociologisk förståelse av specialiseringen av kunskapsområden och professionella praktikområden i det moderna samhället och hur dessa specialiseringsprocesser fungerar och drivs fram i konkurrens med andra grupperingar. 


\section{Referenser}

Abbott, A. (1988). The System of Professions. An essay on the Division of Expert Labor. Chicago: The University of Chicago Press.

Abbott, A. (2005). Linked Ecologies. States and Universities as Environments for Professions. Sociological Theory 23:3, pp 245-274.

Abbott, A. (2010). Varieties of Ignorance. American Sociologist. Volume 41, Number 2, pp 174189.

Bourdieu, P. (1973). The three forms of theoretical knowledge. Social Science Information 197312 pp 53-80.

Bourdieu, P. (1977). Outline of a theory of practice. Cambridge: Cambridge University Press.

Bourdieu, P. (1991). Language and Symbolic Power. Cambridge: Polity Press.

Bourdieu, P. (1990). The Logic of Practice. Cambridge Polity Press.

Bourdieu, P. (1992). Texter om de intellektuella. Stockholm: Brutus Östling förlag.

Bourdieu, P. (1995). Praktiskt förnuft. Bidrag till en handlingsteori. Göteborg: Daidalos.

Bourdieu, P. (1996a). The State Nobility. Elite Schools in the Field of Power. Cambridge: Blackwell \& Polity Press.

Bourdieu, P. (1996b). Homo Academicus. Stockholm: Brutus Östlings förlag.

Bourdieu, P. (2000). Konstens regler. Det litterära fältets uppkomst och struktur. Stockholm: Brutus Östlings förlag.

Bourdieu, P. (2004).The mystery of the Ministry: From particular will to the general will. Constellations 11, nr. No 1, pp 37-43.

Bourdieu, P. (2005). Representationens magi: Fra individuelle viljer till "almenviljen. Social kritik 100, pp 50-57.

Bourdieu, P. \& Passeron, J-C. (1979). The Inheritors. French students and their relation to cul ture. Chicago: The University of Chicago Press.

Bourdieu, P. \& Passeron, J-C. (2008) Reproduktionen. Bidrag till en teori om utbildningssystemet. Lund: Arkiv.

Bourdieu, P.; Passeron, J-C. \& de Saint Martin, M. (1994). Academic Discourse. Linguistic Misun- derstanding and Professorial Power. Stanford: Stanford University Press.

Brante, T. (2010). Professional Fields and Truth Regimes: In Search of Alternative Approaches. Comparative Sociology, 2010, 9, 6, pp 843-886.

Broady, D. (1991). Sociologi och epistemologi: om Pierre Bourdieus författarskap och den historiska epistemologin Diss. Stockholm: HLS förlag.

Callewaert, S. (1997). Bourdieustudier. Institut för Filosofi, Pædagogik og Retorik, Københavns Universitet.

Callewaert, S. (1998). Bourdieustudier 2. Institut för Filosofi, Pædagogik og Retorik, Københavns Universitet.

Callewaert, S. (1999) Towards a general theory of professional knowledge and action. In Nordisk Pedagogik. Vol. 19, nr 4, pp 209-222.

Callewaert, S. (2006). Ett collage om livshistoria och konst, för att glömma pedagogiken för en stund. I M. Börjesson, I. Heyman, M Langerth Zetterman, E. Larsson, I. Lidegran och M. Palme, Fältanteckningar. Utbildnings- och kultursociologiska texter tillägnade Donald Broady, Uppsala universitet, pp. 323-338.

Capra, F. (1997). The Web of Life: A New Understanding of Living Systems. - London: Anchor Books/Doubleday.

Carlhed, C. (2007). Medicinens lyskraft och skuggor. Om trosföreställningar och symbolisk makt $i$ habiliteringen 1960-1980. Uppsala Studies in Education 116. Diss.

Carlhed, C. (2008). Pionjärer, avfällingar och kättare. I Petersen, K-A. \& Høyen, M. (Red.). At saette spor på en vandring fra Aquinas til Bourdieu - aeresbog til Staf Callewaert. Hexis forlag, pp 257-272.

Eklöf, M. (2000). Läkarens ethos. Studier $i$ den svenska läkarkårens identiteter, intressen och ideal 1890-1960. Linköping Studies in Arts and Science 216. Diss.

Petersen, K A. (1996). Den situationsbundne kundskab- om praktikernes egenlogik, In: Jørgensen, Emmy Brandt (red.): Sundhedsvidens-

Carina Carlhed: Fält, habitus och kapital som kompletterande redskap... 
kabelige praktikker. Et bud på fagindhold for medicinsk humaniora. Akademisk Forlag, pp. 321-331.

Petersen, K A. (2004). Om teoriens rolle i professionspraktikker og uddannesler hertil. I K A Petersen (red). Praktikker i erhverv og uddannelse. København: Frydenlund.

Socionomförbundets tidskrift 1975, nr 4, s 8-9.

Svensson, L G. (2010). Professions, organizations, collegiality and accountability. In Lennart G
Svensson and Julia Evetts (Eds.) Sociology of professions. Continental and Anglo-Saxon Traditions. Göteborg: Daidalos.

Svensson, L G. \& Evetts, J. (Eds.) (2010). Sociology of professions. Continental and Anglo-Saxon Traditions. Göteborg: Daidalos.

Wingfors, S. (2004). Socionomyrkets professionalisering. Göteborg Studies in Sociology 20. Göteborg: Göteborgs universitet. Diss.

Denna artikel är en del av ett större forskningsprojekt, Kunskapssamhällets bärare, finansierat av Vetenskapsrådet.

\section{Summary}

\section{Field, habitus and capital as supplementary tools in research on professions}

The aim of this article is to explore how Bourdieu's perspective can contribute to the field of research on professions. A comparison was made between Bourdieu's perspective and Andrew Abbott's work The System of Professions, which was chosen as a reference and a representation of sociology of professions. A specific issue was to be answered: what in particular can Bourdieu's perspective contribute with and how could it complement theory of professions. In sum, between Abbott and Bourdieu there are interesting parallels; the conflict perspectives, relational thinking, emphasis on empirical research starting with rather "loose" definitions, concepts as frameworks which needs to be filled empirically in order to reach full potential and meaning, knowledge as a legitimizing resource and split between practical knowledge and academic knowledge, cultural and (legal) legitimacy of authority, image making and ideology production and an inclination to emphasize structural agency. The comparison also revealed some differences in their focus on; the significance of socioeconomic stratification and reproduction, boundaries and core areas; symbolic and cultural assumptions on social practice, agents in formation of a field vs. a system, and finally on the detail contributions on professional activity on tasks. Bourdieu's particular contribution lies mainly on the mechanisms of socialization and reproduction to the fields and decomposition of the concepts of class and professions, which means a broader and more profound understanding on relations of dominance and their social and cultural rudiments. 